\title{
Genetic diversity and population structure of Siganus fuscescens across urban reefs of Seribu Islands, Northern of Jakarta, Indonesia
}

\author{
ADITYA BRAMANDITO ${ }^{1}$, BEGINER SUBHAN ${ }^{1}$, TRI PRARTONO ${ }^{1}$, NURLITA PUTRI ANGGRAINI ${ }^{1}$, \\ HEDI INDRA JANUAR ${ }^{2}$, HAWIS H. MADDUPPA ${ }^{1, \vee}$ \\ ${ }^{1}$ Department of Marine Science and Technology, Faculty of Fisheries and Marine Science, Institut Pertanian Bogor. Jl. Raya Darmaga, Bogor 16680, \\ West Java, Indonesia. Tel./fax.: +62-251-8623644, ’email: hawis@apps.ipb.ac.id \\ ${ }^{2}$ Indonesian Research Center for Marine and Fisheries Products Processing and Biotechnology. Jl. KS.Tubun, Petamburan, Jakarta Pusat 10260, Jakarta, \\ Indonesia
}

Manuscript received: 20 August 2018. Revision accepted: 8 October 2018

\begin{abstract}
Bramandito A, Subhan B, Prartono T, Anggraini NP, Januar HI, Madduppa HH. 2018. Genetic diversity and population structure of Siganus fuscescens across urban reefs of Seribu Islands, Northern of Jakarta, Indonesia. Biodiversitas 19: $1993-2002$. Jakarta bay and Seribu Islands reefs have been affected by anthropogenic activities which causing them degraded and low quality of the ecosystem. However, lack of study has been conducted to investigate the effect on reef fish population due to change in ecosystem quality. Therefore, this study was undertaken to analyze genetic diversity and population structure of Siganus fuscescens population against heavy metals $(\mathrm{Pb}, \mathrm{Cd}$, and $\mathrm{Cu})$ concentration across Jakarta Bay and Seribu Islands environmental gradient. Genetic diversity and structuring of $S$. fuscescens populations were determined using partial sequences of the mitochondrial cytochrome $\mathrm{C}$ oxidase I. Monitoring of heavy metal was measured by Atomic Absorption Spectroscopy (AAS) shows highest concentration of heavy metal ( $\mathrm{Pb}$, $\mathrm{Cd}$, and $\mathrm{Cu}$ ) was observed in the southern of Seribu Islands, closest to Jakarta. However, the diversity of haplotype obtained from each location indicates a varied range between 0,1429 (Pramuka Island, located in the center) and 0,75 (Untung Jawa Island, located in the south). Linear regression test reveals that $\mathrm{Cu}$ elements had a moderate effect $\left(\mathrm{R}^{2}\right.$ adjusted $\left.=0.665\right)$ to the nucleotide diversity of the fish. The study shows some populations of $S$. fuscescens have been affected by heavy metal and could be an alarm to manage this artisanal targeted fish in the Seribu Islands.
\end{abstract}

Keywords: Genetic differentiation, heavy metal, population connectivity, reef fishes, urban ecosystem

\section{INTRODUCTION}

Fish is one of the income and protein sources for million people worldwide (Jennings and Polunin 1996; Allison and Ellis 2001; Badjeck et al. 2010). In contrary, social inequality combined with vast natality rate causes stressed condition in reef fish population, which further can affect the health of an ecosystem (Miller and Sweatman 2004; Wilkinson 2008; Burke et al. 2012). After being damaged, coral reef ability to recover depends on some factors, including the initial condition of the ecosystem and the extent to which the cause of the degradation has been eliminated.

The number of ecological indicators has been developed to determine the condition of the aquatic ecosystem. This includes the indicator based on abundance of a specific species, e.g., Chaetodontidae family or other herbivorous fish (Crosby and Reese 1996; Kulbicki et al. 2005; Hoey and Bellwood 2011); the relationship between reef fish and its habitat in coral reef (Madduppa et al. 2012, Madduppa et al. 2013; Nugroho et al. 2018) to the fisheries utilization as bio-indicator of heavy metal exposure (Authman et al. 2015). Low level of pollution exposure may not have any detrimental effect on fish. However, it can affect fish fertility that leads to population degradation (Madduppa et al. 2018). As the population number decreases, genetic shifting increases and allele will subside (Garza and Williamson 2001). Another impact from population degradation is the high number of heterozygosity and allele eradication as their potential to become homozygous increases (inbreeding depression) (Lande 1988). The decline in genetic diversity and heterozygosity can be observed in the bottlenecked population (England et al. 2003). Recent studies have indicated the impact of global climate change on genetic diversity of organisms (Bálint et al. 2011).

The impact of pollution on fish length as one of the health parameters of fish populations began to be studied by Zhang et al. (2008) stating that the size of certain types of fish will have a negative correlation with pollutant content. Further research was conducted by Kousar and Javed (2015) where freshwater fish exposed to heavy metals for 30 days would have genetic damage. Spielman et al. (2004) reported that $77 \%$ of 170 taxa were threatened with lower heterozygosity than other taxa that were not threatened. Unawareness of the decline in genetic diversity occurs due to its long-term and invisible effects, compared to its visual impact on the population (Frankham 1995). Seribu Islands, a group of 110 islands located north of Jakarta with around 25 million inhabitants (Brinkhoff 2011), represents an ideal area to assess the relative effects of multiple stressors on coral reef ecosystems. Here, a marked inshore-offshore gradient in heavy metal pollution, nutrient input (Williams et al. 2000; Cleary et al. 2006), coral cover (Fahlevy et al. 2017) and fish abundance 
(Fahlevy et al. 2018) has been observed.

In this study, the Siganus fuscescens fish genetic diversity and population structure in the Seribu Islands based on partial sequences of mitochondrial cytochrome oxidase I (COI) genes was investigated. The presence of $S$. fuscescens fish is essential because they categorized as a functional group as browsers, which is a group of herbivorous fish that play an important role in reducing overgrowth and shading by macroalgae (Woodland 2001; Hoey and Bellwood 2013).

\section{MATERIALS AND METHODS}

\section{Study sites}

The location of Siganus fuscescens fish sampling was in the Seribu Islands region, North Jakarta, specifically in Kelapa Island (14 samples), Pramuka Island (14 samples), Panggang Island (13 samples), Semak Daun Island (16 samples), Bokor Island (7 samples), Untung Jawa Island (8 samples) and Damar Island (5 samples) (Figure 1). Sampling conducted in May 2015-October 2015 using gill nets and a total sample of 77 fish was obtained with an average length of $14.95 \pm 2.26 \mathrm{~cm}$ and an average weight of $59.87 \pm 28.26 \mathrm{~g}$. Collected fish, water, and sediment samples were preserved in an ice box and transferred to the laboratory after weighed and measured by total length until further analysis.

\section{DNA extraction, amplification, and sequencing}

All DNA samples were extracted using RNeasy 96 KitQiagen derived from fish fin tissue that had been preserved using 96\% alcohol. GeneRulerTM 1kb DNA Ladder Plus (Applied Biosystems) is used as a reference. Polymerase Chain Reaction (PCR) is performed with a $25 \mu \mathrm{L}$ total volume consisting of $2.5 \mu \mathrm{L} 10 \times$ PCR buffer, $3 \mu \mathrm{L} 25 \mathrm{mM}$ $\mathrm{MgCl} 2,1 \mu \mathrm{L} 2 \mathrm{mM} \mathrm{dNTP}, 1 \mu \mathrm{L}$ every $10 \mathrm{mM}$ forward and reverse primer, $0.1 \mu \mathrm{L}(5$ units $/ \mu \mathrm{L})$ Taq polymerase (F100L Taq DNA), and $1 \mu \mathrm{L}$ (1-10 ng) extract DNA. The primer used in the PCR method is COI $501 \mathrm{~F}$ 5'CATGAAACCTCCYGCTATYTCC3 'COI 1286R 5'TGTTGTGGGAAGAAAGTYAGRTT3' (Ivanova 2007). The optimum PCR condition used is the initial denaturation cycle at $94^{\circ} \mathrm{C}$ for 30 seconds followed by 35 repeated annealing cycles at $52^{\circ} \mathrm{C}$ for 35 seconds and an additional cycle at 70 for one minute. The finished PCR product was then assessed using electrophoresis gel made from $0.75 \mathrm{~g}$ of agarose $1 \%$, buffer $75 \mathrm{ml}$ and ethidium bromide dye 4 $\mu \mathrm{L}$ then observed visually with UV light emitting device Protein simple-Alpha imager mini. All optimal PCR products are sent to the 1st Base company in Malaysia for sequencing.

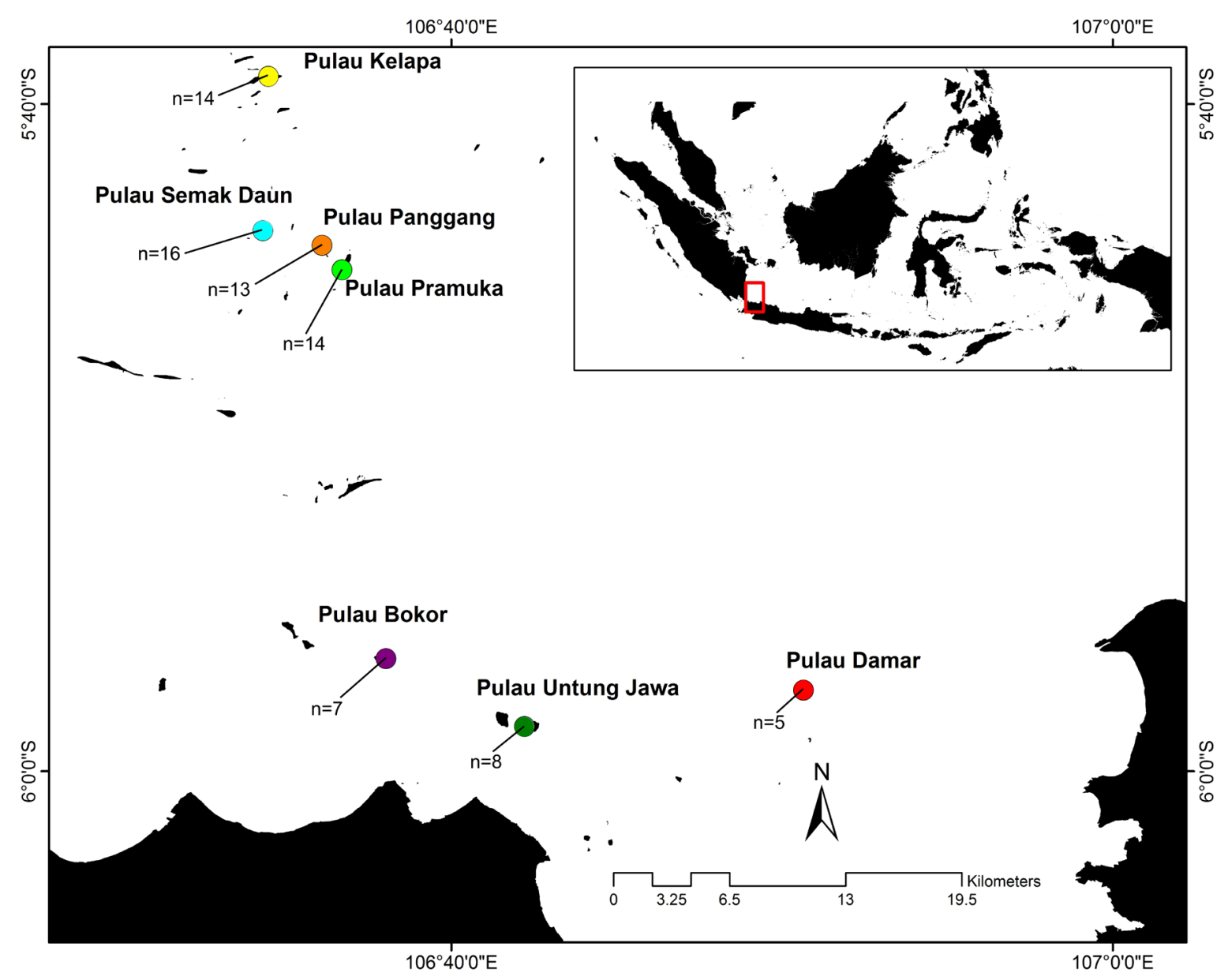

Figure 1. The localities (circles) of samples of Siganus fuscescens used for the analyses of population structure in Seribu Islands, Northern of Jakarta, Indonesia in this study 


\section{Water and sediment collection}

Preparation of subsamples and analysis were made according to FAO (1983), APHA (2012), and BSN (2011). Sediment samples from each station were collected using Ekman grab. The top 3-5 cm of each sediment samples were placed in a polyethylene plastic bag with a plastic spoon as much $500 \mathrm{~g}$. Water samples were taken with the Van Dorn Water Sampler (PVC material with a capacity of 2 liters) in the coating surface (approximately at a depth of $50-100 \mathrm{~cm}$ ). The water sample was then removed into a bottle of polyethylene sample with a volume of 1 liter and stored in an ice box.

\section{Water, sediment and muscles digestion}

Analysis of heavy metal content in seawater was done by adding $5 \mathrm{ml}$ of $\mathrm{HNO}_{3} 1 \mathrm{~N}$ and heated, aquadest were added into the solution and shaked until homogenous, followed by analysis using Atomic Absorption Spectroscopy (AAS) at $283.3 \mathrm{~nm}$ wavelength. Sediment was dried at $105^{\circ} \mathrm{C}$ for 5 hours and then cooled in a desiccator for 30 minutes. Meanwhile, muscle samples were dried at $-40^{\circ} \mathrm{C}$ for 4 hours. The smoothed sample was then dissolved as much as $10 \mathrm{~g}$ with $\mathrm{HNO}_{3}$ and filtered using Whatman filter paper grade 1: $11 \mu \mathrm{m}$ (medium flow filter paper). The mixture was then added aquadest up to 50 $\mathrm{ml}$ volume and ready to be analyzed using AAS at 283.3 $\mathrm{nm}$ wavelength. The obtained results were expressed as ppm. $\square$

\section{Data analysis}

The results of DNA sequencing were aligned and edited using MEGA version 6.0 software. Phylogenetic analysis was prepared using MEGA software version 6.0 (reference) with the Neighbor-Joining (NJ) method. The estimation of confidence interval used was a bootstrap analysis of 1000 replications. Paired genetic distance test (D), haplotype diversity (h) and nucleotide diversity $(\pi)$ were calculated using the DnaSP version 5.10 software (Rozas et al. 2003). Population differences from each population are assessed using the Fixation index (Fst) and Analysis of Molecular Variance (AMOVA) values were analyzed using ARLEQUIN v3.5 software (Excoffier and Lischer 2009).

Data processing was carried out by descriptive analysis, non-parametric Spearman correlation, multivariable Principal Component Analysis (PCA), and linear enter and stepwise regression. Descriptive analysis and Spearman non-parametric correlations were conducted to determine trends in the value of heavy metal pollution and fish genetic diversity between locations. Meanwhile, PCA analysis was accomplished to ascertain the pattern of heavy metal pollution in different location groups, as well as the level of diversity of haplotypes and nucleosides. The grouping of locations for heavy metal pollution in the southern area (Untung Jawa, Damar, and Bokor), central (Pramuka and Panggang), and north (Semak Daun and Kelapa). Haplotypes diversity and nucleotide diversity are grouped based on the distribution of the highest and lowest values obtained, namely high, moderate, and low. Data transformation is done using the $\log$ function, to meet standard requirements in multivariable analysis and enter and stepwise linear regression. All statistical analyzes were performed using PAST Statistical Software v3.0 and SPSS ver 15 software (Hammer et al. 2001)

\section{RESULTS AND DISCUSSION}

\section{Phylogenetic analysis and genetic diversity}

The total samples of Siganus fuscescens from seven locations were of 77 individuals, with a segment length of sequenced cytochrome $\mathrm{C}$ oxidase I (COI) of 433 base pairs (bp). A phylogenetic tree using the neighbor-joining (NJ) method (Figure 2) shows that there are five lineages; clade A, B, C, D and E (Figure 2). Clade A and Clade B have high Bootstrap Probability (BP) (>50) while in Clades $\mathrm{C}$, $\mathrm{D}$ and $\mathrm{E}$ have $\mathrm{BP}$ less than 50. Clade $\mathrm{A}$ and $\mathrm{B}$ form a monophyletic group that is only in one location. Clade $\mathrm{C}$ has a limited distribution area which is only found in two sampling locations. Clade D is spread more widely than $\mathrm{C}$ clade, where clade $\mathrm{D}$ can be found in six sampling locations. Clade $\mathrm{E}$ has the most extensive distribution that appears at each sampling location.

There were nine haplotypes found in the Seribu Islands, two haplotypes were part of several fish populations that differed in geographic location, and seven other haplotypes were singletons. Semak Daun Island and Untung Jawa Island are locations where haplotypes found in $S$. fuscescens fish have more than three haplotypes (Table 1). The results of the Minimum Spanning Network (MSN) analysis of $S$. fuscescens haplotypes showed that the northern part of the Seribu Islands shared a haplotype with the southern region of the Seribu Islands on H_1 (Figure 3).

\section{Population structure}

The diversity of haplotype (h) obtained from each location is varied ranged between $0.1429-0.7500$. The highest haplotype value $(0.7500)$ is recorded from Untung Jawa Island while the lowest value (0.1429) is observed in Pramuka Island. Akbar et al. (2014) suggest that the number of haplotypes and haplotype diversity would affect the genetic diversity of a population. The value of nucleotide diversity in each location has a range of 0.0003 0.0142 with the lowest value found in Pramuka Island and the highest value is found in Kelapa Island. Based on the haplotype network and genetic diversity obtained from the study, Untung Jawa Island is considered as 'hotspot' for the S. fuscescens fish population in the Seribu Islands.

The genetic distance value obtained from the analysis of the Kimura-2 parameter (K2P) method shows the range of genetic distance values of the $S$. fuscescens fish population is between 0.00036-0.01410 (Table 2). The genetic distance value is a value scale that describes the similarity of the base sequence in the $\mathrm{CO} 1$ gene fragment, the smaller the value, the closer the kinship relationship between the two populations (Nei 1972). The genetic distance value of fish populations between each island in this study indicates that the distance factor is one of the factors that cause differences in genetic distance values, the 
farther the distance between populations, the higher the genetic distance value. It can be seen that the genetic distance value of the $S$. fuscescens fish population in Pramuka Island with Panggang Island has the smallest value where the positions of the two islands are close together $(1.3 \mathrm{Km})$. Similar conditions are also found in most fish populations on each island, but some anomalies occur in the genetic distance value obtained in Kelapa Island with Damar Island. The position of Damar Island with Kelapa Island is separated by the farthest distance $(44.7 \mathrm{Km})$ while the highest genetic distance value is found in the $S$. fuscescens fish population on Untung Jawa Island with Kelapa Island. The anomaly seems to occur due to the geographical position of Damar Island that was separated from the island group and the egg phase of S. fuscescens fish that are demersal or attached to an object (Duray and SAFDC, 1998) so that gene flow into the $S$. fuscescens fish population found Damar Island is insignificant.

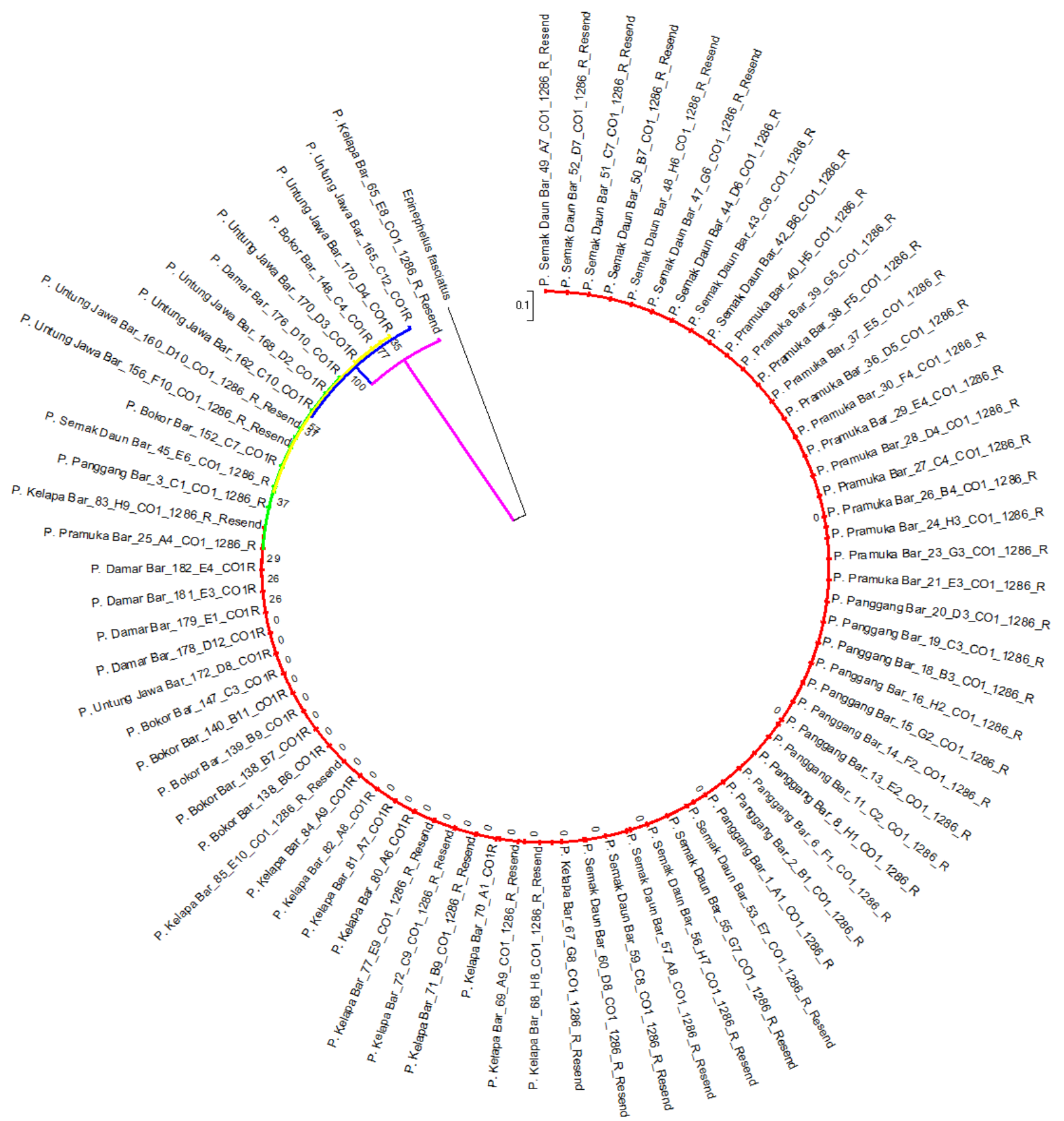

Figure 2. Neighbor-joining tree constructed from the mitochondrial cytochrome C oxidase I gene sequences (433 bp) of Siganus fuscescens. The evolutionary distances were calculated based on Kimura's two-parameter model. Purple show clade A, Blue show clade B, Yellow show clade C, Green show clade D, and red show clade E 
Analysis of Molecular Variation (AMOVA) using a confidence interval of 0.005 was used to observe the statistical differences in genetic distances between populations in the Seribu Islands (Table 3). The results of the analysis showed that there were significant differences between fish populations throughout the sampling location $($ Fst $=0.1066$ and $p$-value $=0.00587)$. Other spatial comparisons were made by dividing the seven sampling locations into two groups: the northern of the Seribu Islands ( Kelapa Island, Pramuka Island, Panggang Island and Semak Daun Island) and the south of the Seribu Islands (Untung Jawa Island, Bokor Island and Damar Island). Fst value $=0.1461$ and $\mathrm{P}=0.0000$ shows that there is a significant difference between the fish population on the North side of the Seribu Islands and the fish population on the South side of the Seribu Islands. Another AMOVA test was conducted by dividing fish sampling locations on populated islands, and uninhabited islands showed that there were no significant differences for these two groups
$($ Fst $=0.0000$ and $p$-value $=0.82698)$. Limited distribution has been observed in a small scale genetic population structure of coral reef organisms in the Spermonde Archipelago, Indonesia (Timm et al. 2017)

Table 1. Genetic diversity of $S$. fuscescens accessed from the number of the haplotype (Hn), Haplotype diversity (h) and Nucleotide diversity $(\pi)$. $\mathrm{n}$ shows the number of samples in each locality.

\begin{tabular}{lcccc}
\hline \multirow{2}{*}{ Research site } & \multirow{2}{*}{} & \multicolumn{3}{c}{ Genetic diversity } \\
\cline { 3 - 5 } & & Hn & $\boldsymbol{h}$ & $\boldsymbol{\pi}$ \\
\hline Untung Jawa & 8 & $\mathbf{4}$ & $\mathbf{0 . 7 5 0 0}$ & 0.0080 \\
Damar & 5 & 2 & 0.4000 & 0.0010 \\
Bokor & 7 & 3 & 0.5238 & 0.0038 \\
Pramuka & 14 & 2 & $\mathbf{0 . 1 4 2 9}$ & $\mathbf{0 . 0 0 0 3}$ \\
SemakDaun & 16 & 3 & 0.2417 & 0.0006 \\
Panggang & 13 & 2 & 0.1538 & 0.0004 \\
Kelapa & 14 & 2 & 0.2747 & $\mathbf{0 . 0 1 4 2}$ \\
\hline
\end{tabular}

Table 1. Genetic distance value of $S$. fuscescens fish populations in each study sites in Seribu Islands, Northern of Jakarta, Indonesia

\begin{tabular}{|c|c|c|c|c|c|c|c|c|}
\hline No & Site & 1 & 2 & 3 & 4 & 5 & 6 & 7 \\
\hline 1 & Damar & - & - & - & - & - & - & - \\
\hline 2 & Untung Jawa & 0.00631 & - & - & - & - & - & - \\
\hline 3 & Bokor & 0.00228 & 0.00675 & - & - & - & - & - \\
\hline 4 & Pramuka & 0.00065 & 0.00684 & 0.00225 & - & - & - & - \\
\hline 5 & Panggang & 0.00059 & 0.00653 & 0.00215 & 0.00036 & - & - & - \\
\hline 6 & Semak Daun & 0.00072 & 0.00671 & 0.00229 & 0.00047 & 0.00046 & - & - \\
\hline 7 & Kelapa & 0.00800 & 0.01410 & 0.00961 & 0.00769 & 0.00770 & 0.00782 & - \\
\hline
\end{tabular}

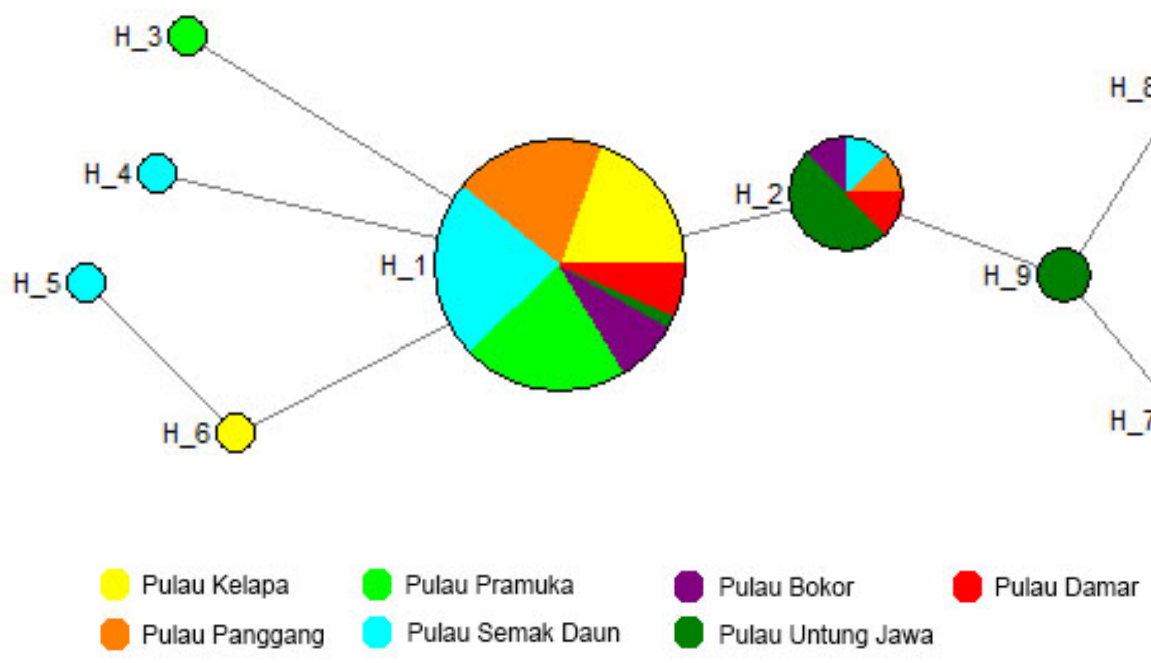

Figure 3. Minimum Spanning Network of Haplotypes for $S$. fuscescens based on the mitochondrial COI gene sequences (433 bp) identified in 77 individuals from seven geographic population of Seribu Islands, Northern of Jakarta, Indonesia. Each circle represents a unique haplotype, and pie slices represent a fraction of geographic populations, Size of circles is proportional to the number of individuals $\square$ 
Studies conducted by Masigno and Juino-Menez (2008) show similar results, where the $S$. fuscescens fish population was spatially structured on the eastern coast of the Philippines $\left(\mathrm{F}_{\mathrm{ST}}=0.03275 ; \mathrm{P}<0.05\right)$. A similar result is also found in the study conducted by Yagishita and Yamaguchi (2016) in $S$. fuscescens fish populations in Okinawa waters and several islands in North Kyushu which had a significant difference $\left(\mathrm{F}_{\mathrm{ST}}=0.1817-0.2465 ; \mathrm{P}=\right.$ 0.0000-0.001). Duray and SAFDC (1998) state that most fish eggs from the Siganidae family have properties attached to the substrate and the egg phase only lasts for a few days. This indicates that $S$. fuscescens have a closed genetic flow system. Theoretically, the population of biota with a closed genetic flow system has greater potential to reproduce inbreeding and indirectly affect the ability to survive against the pressure of ecology or polluted environmental conditions (Reusch et al. 2005; Hoffman and Parsons, 1991).

\section{Heavy metal concentration}

The heavy metal elements contained in the sediments at each sampling site of $S$. fuscescens have a pattern that is decreasing from the Southern side to the northern Seribu Islands. The highest concentration of $\mathrm{Pb}$ was observed in Bokor Island which is geographically located on the southern Seribu Islands, and the lowest level is on the North side of the Seribu Islands, Kelapa Island. A similar pattern is still seen in $\mathrm{Cu}$ metal elements, where the highest concentration was found on the southern part of the Seribu Islands, Untung Jawa Island and decreases towards the northern part of Seribu Islands, Kelapa Island. Bokor Island has the highest $\mathrm{Cd}$ concentration compared to the level of $\mathrm{Cd}$ element in other locations. Kelapa Island is the location with the lowest concentration of heavy metal elements compared to the other seven islands.

The level of heavy metals in muscle samples of $S$. fuscescens tends to be fluctuating in seven study sites. $\mathrm{Cu}$ metal is an element that was found in most muscle samples with the highest concentration found in samples from Panggang Island, and the lowest concentration was found in samples from Kelapa Island. $\mathrm{Cd}$ is only found in the muscle sample from Bokor Island and Semak Daun Island with a concentration value of $0.37 \mathrm{ppm}$ and $1.6 \mathrm{ppm}$ respectively. The third metal element, $\mathrm{Pb}$, was only found in muscle samples from Untung Jawa Island at the concentration of $0.19 \mathrm{ppm}$ and Pramuka Island at 1.23 ppm.

\section{Correlation between genetic diversity and heavy metal concentration}

The results of the Spearman correlation analysis show that the overall values of heavy metals in waters and sediments are linear, indicating that the three heavy metal elements come from similar sources. The determinant heavy metal element can be seen from the results of the main component analysis with the variables of heavy metals contained in the waters and the sediment (Figure 7). The main component analysis shows that there are two sedimentary metals $(\mathrm{Pb}$ and $\mathrm{Cu})$ that differ between the sampling points of the study (99.5\%). Meanwhile, Cd sediment differentiates by $(0.5 \%)$, or the effect is least significant. Other components only affect $0.1 \%$. This shows that significant differences between research points are two types of metals found in sediments. PCA analysis shows that sampling points in the southern region (Untung Jawa, Damar, and Bokor) tend to have higher levels of $\mathrm{Pb}$ and $\mathrm{Cu}$ compared to sampling points in the central region (Pramuka and Panggang) and the northern region (Semak Daun and Kelapa). Regarding this, it can be suggested that coastal area of Jakarta suspected to be the source of heavy metal pollution in Seribu Island sediment. $\square$

Results obtained from Spearman correlation shows that heavy metals content tested in fish muscle does not have a significant impact on heavy metals content found both in waters and sediment (Table 5). However, result from PCA indicates the higher concentration of heavy metals found in fish sampled from a middle and southern area of Seribu Island compared to samples obtained from northern Seribu Island (86.2\%) (Figure 8).

Table 2. AMOVA results for genetic diversity in S. fuscescens fish populations in the Seribu Islands

\begin{tabular}{|c|c|c|c|}
\hline All samples & $\begin{array}{l}\text { Percentage of } \\
\text { variation }\end{array}$ & Fst & P value \\
\hline Inter population & 10.66 & 0.10662 & 0.00587 \\
\hline Intra population & 89.34 & & \\
\hline \multicolumn{4}{|l|}{ North and south } \\
\hline Inter population & 14.61 & 0.14607 & 0.00000 \\
\hline Intra population & 85.39 & & \\
\hline \multicolumn{4}{|c|}{ Conservation and non-conservation } \\
\hline Inter population & 14.61 & 0.14607 & 0.00000 \\
\hline Intra population & 85.39 & & \\
\hline \multicolumn{4}{|c|}{ Inhabited and uninhabited } \\
\hline Inter population & -1.31 & -0.01314 & 0.82698 \\
\hline Intra population & 101.31 & & \\
\hline
\end{tabular}

Table 4. Spearman (R) correlation was used as a non-parametric statistical test to determine the tendency between two aligned values. If $\mathrm{R}<0.5$ is weak, $5>\mathrm{R}>8$ is moderate, and $\mathrm{R}>8$ is strong

\begin{tabular}{lccccccc}
\hline \multirow{2}{*}{ Sample } & $\begin{array}{c}\text { Spearman } \\
\text { correlation }\end{array}$ & \multicolumn{3}{c}{ Waters } & \multicolumn{3}{c}{ Sediment } \\
\cline { 3 - 8 } & Pb & $\mathbf{C d}$ & $\mathbf{C u}$ & $\mathbf{P b}$ & $\mathbf{C d}$ & $\mathbf{C u}$ \\
\hline Waters & $\mathrm{Pb}$ & 1 & .893 & .857 & .857 & .786 & .929 \\
& & & $(* *)$ & $(*)$ & $(*)$ & $(*)$ & $(* *)$ \\
& $\mathrm{Cd}$ & .893 & 1 & .964 & .964 & .929 & .929 \\
& & $(* *)$ & & $(* *)$ & $(* *)$ & $(* *)$ & $(* *)$ \\
& $\mathrm{Cu}$ & .857 & .964 & 1 & 1.000 & .964 & .964 \\
Sedimentyyyyyyyy & & $(*)$ & $(* *)$ & & $(* *)$ & $(* *)$ & $(* *)$ \\
& & .857 & .964 & 1.000 & 1 & .964 & .964 \\
& & $(*)$ & $(* *)$ & $(* *)$ & & $(* *)$ & $(* *)$ \\
& $\mathrm{Cd}$ & .786 & .929 & .964 & .964 & 1 & .929 \\
& & $(*)$ & $(* *)$ & $(* *)$ & $(* *)$ & & $(* *)$ \\
& $\mathrm{Cu}$ & .929 & .929 & .964 & .964 & .929 & 1 \\
& & $(* *)$ & $(* *)$ & $(* *)$ & $(* *)$ & $(* *)$ & \\
\hline
\end{tabular}

Note: $(*)$ Correlation is significant at the 0.05 level (2-tailed). $(* *)$ Correlation is significant at the 0.01 level (2-tailed) 


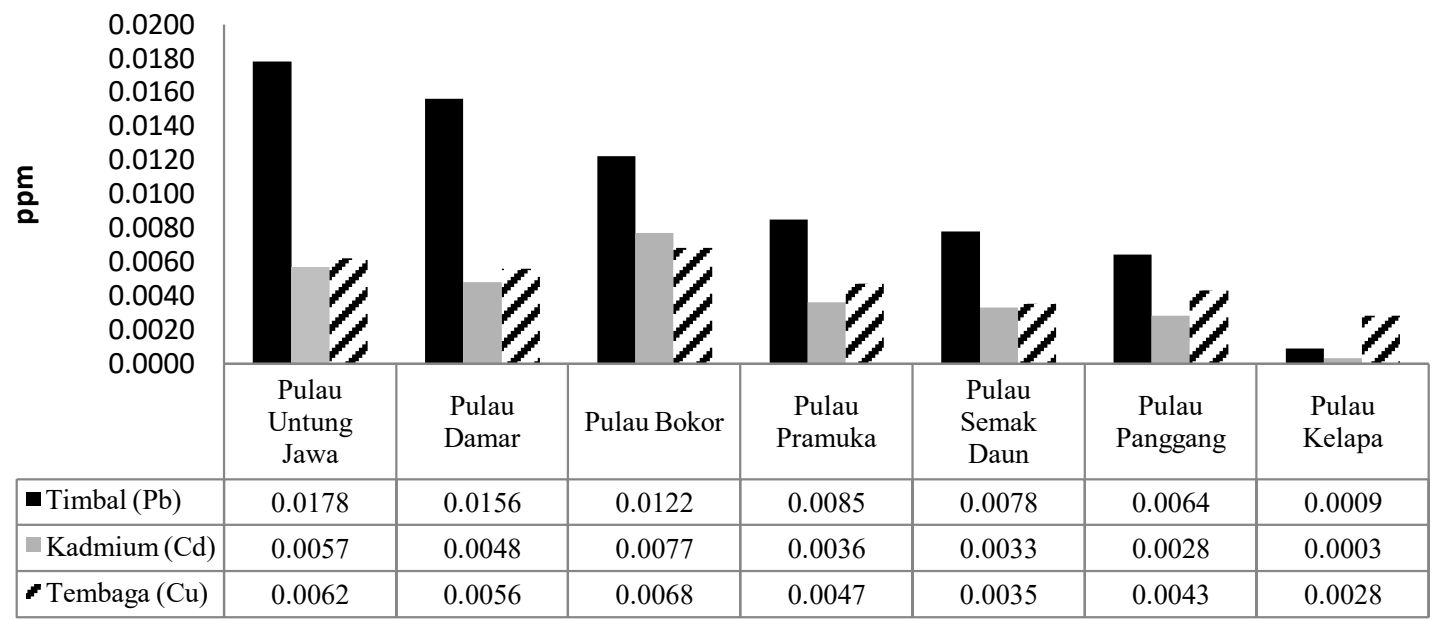

Figure 4. The result of dissolved heavy metal elements of Lead $(\mathrm{Pb})$, Cadmium $(\mathrm{Cd})$ and Copper $(\mathrm{Cu})$ at each sampling location of $S$. fuscescens in the Seribu Islands, Northern of Jakarta, Indonesia

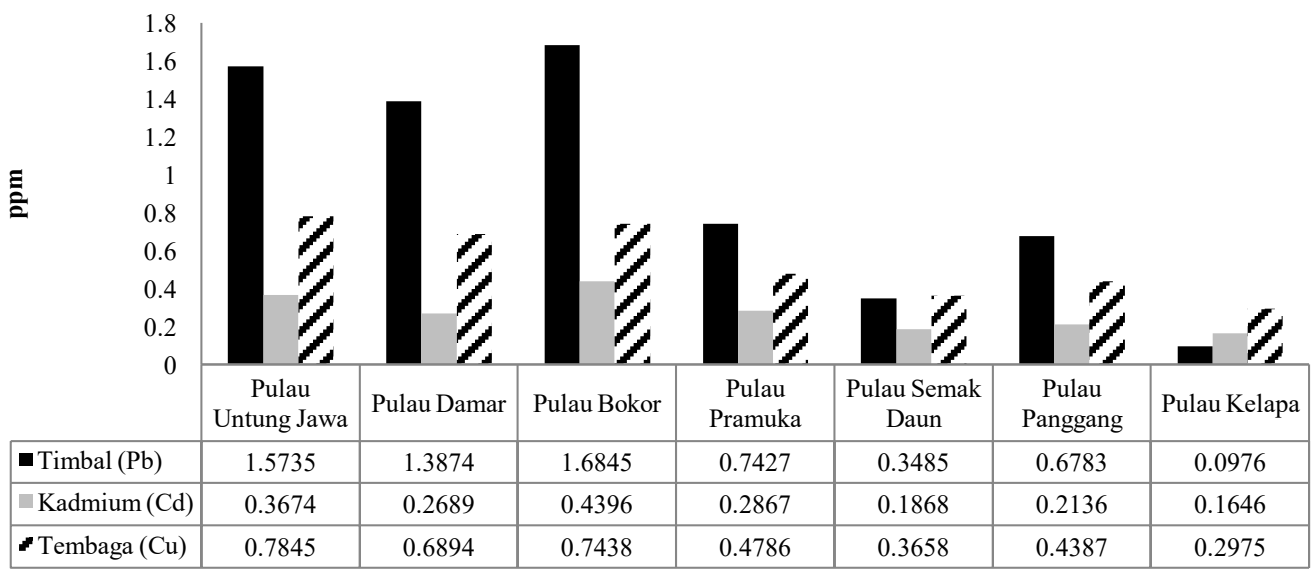

Figure 5. Results of heavy metal elements of lead $(\mathrm{Pb})$, cadmium $(\mathrm{Cd})$ and copper $(\mathrm{Cu})$ in sediments at each sampling location of $S$. fuscescens in the Seribu Islands, Northern of Jakarta, Indonesia

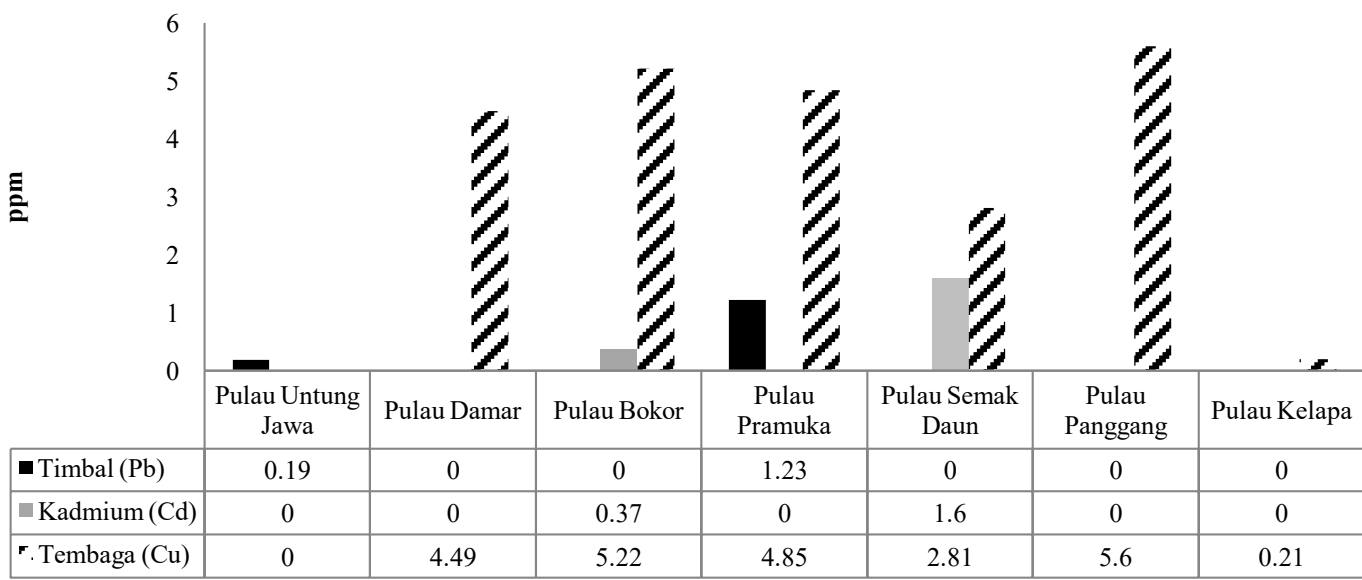

Figure 6. Results of heavy metals elements of lead $(\mathrm{Pb})$, cadmium $(\mathrm{Cd})$ and copper $(\mathrm{Cu})$ in muscle samples of $\mathrm{S}$. fuscescens in the Seribu Islands, Northern of Jakarta, Indonesia 


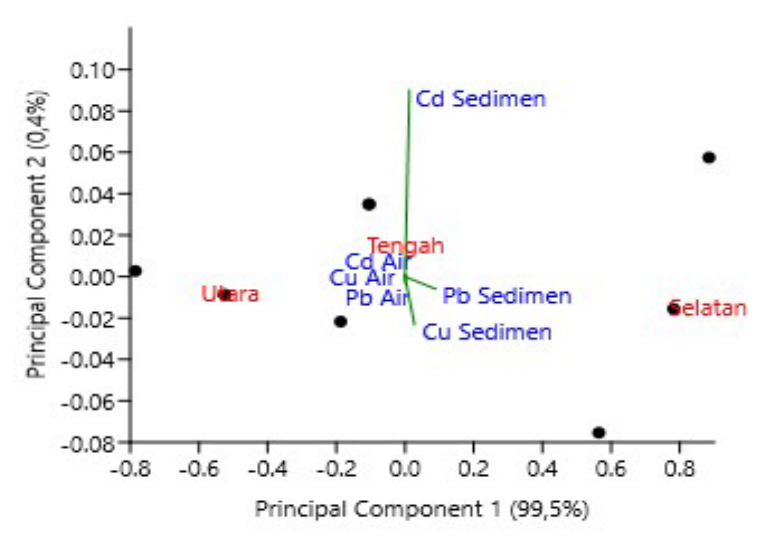

Figure 7. Principal Component Analysis (PCA) of dissolved Pb, $\mathrm{Cd}$, and $\mathrm{Cu}$ with heavy metals contained in sediment. Study sites are categorized into three groups: the southern area (Untung Jawa, Damar, and Bokor), the middle area (Pramuka and Panggang), and the northern area (Semak Daun and Kelapa)

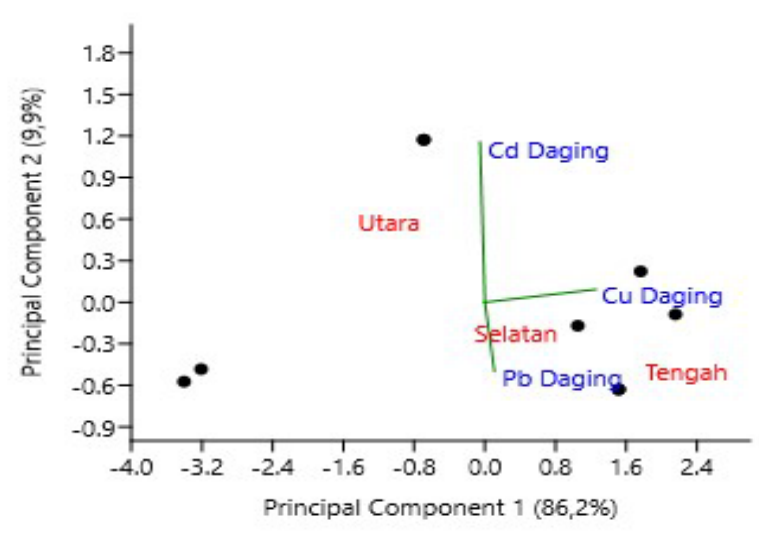

Figure 8. Principal Component Analysis (PCA) of dissolved $\mathrm{Pb}$, $\mathrm{Cd}$ and $\mathrm{Cu}$ with heavy metals contained in fish muscle. Study sites were categorized into three groups, the southern area (Untung Jawa, Damar, and Bokor), the middle area (Pramuka and Panggang), and the northern area (Semak Daun and Kelapa)

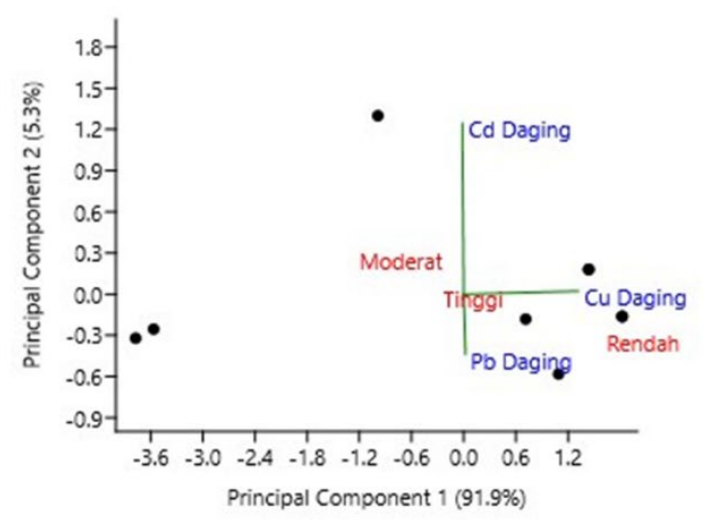

A

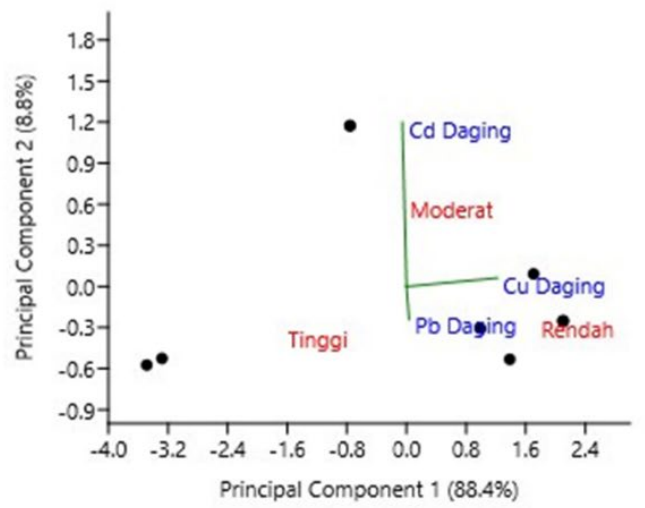

B

Figure 9. Principal Component Analysis (PCA) of heavy metals contained in fish muscle with haplotype diversity (A) and nucleotide diversity (B). Study sites are categorized into three groups; they are the southern area (Untung Jawa, Damar, and Bokor), middle area (Pramuka and Panggang), and northern area (Semak Daun and Kelapa) $\square$

Table 5. Spearman $(\mathrm{R})$ correlation is used as a non-parametric statistical test to determine the tendency between two aligned values. If $\mathrm{R}$ $<0.5$ is weak, $5>\mathrm{R}>8$ is moderate, and $\mathrm{R}>8$ is strong

\begin{tabular}{cccccccc}
\hline \multirow{2}{*}{ Sample } & Spearman & \multicolumn{3}{c}{ Waters } & \multicolumn{3}{c}{ Sediment } \\
\cline { 3 - 8 } & correlation & $\mathbf{P b}$ & $\mathbf{C d}$ & $\mathbf{C u}$ & $\mathbf{P b}$ & $\mathbf{C d}$ & $\mathbf{C u}$ \\
\hline \multirow{2}{*}{ Muscle } & $\mathrm{Pb}$ & 0.401 & 0.267 & 0.267 & 0.267 & 0.445 & 0.401 \\
& $\mathrm{Cd}$ & -0.045 & 0.223 & 0.045 & 0.045 & 0.045 & -0.089 \\
& $\mathrm{Cu}$ & -0.214 & 0.036 & 0.179 & 0.179 & 0.214 & 0 \\
\hline
\end{tabular}

Based on the description, haplotype and nucleotide diversity data are not showing the similar pattern with heavy metal contents in waters and sediment. However, heavy metals level found in fish muscle affects the genetic diversity from individual fish. This can be reviewed from the result of PCA of heavy metal pollution level on Haplotype diversity (A) and nucleotide diversity (B). The value of haplotype component 1 of $91.9 \%$ and nucleotide of $88.4 \%$ shows that bio-accumulation of heavy metals level becomes the major component in this study which plays an important role in haplotype and nucleotide diversity. Component 1 is affected by $\mathrm{Cu}$ value contained in muscle. This leads to the assumption that $\mathrm{Cu}$ elements affect the haplotype and nucleotide diversity more, although elements that are found in high concentration in waters and sediments is $\mathrm{Pb}$. Quantification of bio- 
accumulation of $\mathrm{Cu}$ level as a determinant of fish genetic can be seen in stepwise linear regression analysis.

Stepwise linear regression analysis does not show the independent variable of $\mathrm{Pb}, \mathrm{Cd}$, and $\mathrm{Cu}$ concentration level as a significant determinant to haplotype diversity. Comparison of linear regression with the overall independent variables (linear regression enter) gets the value of determination (adjusted $\mathrm{R}^{2}$ ) of 0.302 (Table 6), which shows that the determination of bioaccumulation as a predictor of haplotypes is low. However, stepwise linear regression testing (linear regression that only takes variables that have a significant effect on $\mathrm{P}<0.05$ ) shows that $\mathrm{Cu}$ levels become a strong determinant of nucleotide diversity.

Determination value (adjusted $\mathrm{R}^{2}$ ) of 0.665 from $\mathrm{Cu}^{\mathrm{s}} \mathrm{s}$ bioaccumulation level on nucleotide diversity showed that $\mathrm{Cu}$ had a moderate influence on the nucleotide genetic diversity of fish (Table 7). This indicates that although $\mathrm{Cu}$ is not a major heavy metal pollutant in Jakarta bay waters, bioaccumulation in fish can significantly affect the genetic diversity of fish found in these waters.

Table 6. Enter linear regression test with dependent variable haplotype and bioaccumulation of $\mathrm{Pb}, \mathrm{Cd}$, and $\mathrm{Cu}$, as independent

Coefficient (a)

\begin{tabular}{llccccc}
\hline \multirow{2}{*}{ Model } & \multicolumn{2}{c}{$\begin{array}{c}\text { Unstandardized Standardized } \\
\text { coefficients } \\
\text { coefficients }\end{array}$} & $\begin{array}{c}\text { t } \\
\text { Beta }\end{array}$ & Sig. \\
\hline & B & SE & SE \\
\hline 1 & (Constant) & .530 & .189 & & 2.809 & .067 \\
& Pb_Daging & -.137 & .244 & -.284 & -.560 & .614 \\
& Cd_Daging & -.083 & .183 & -.225 & -.452 & .682 \\
& Cu_Daging & -.037 & .046 & -.400 & -.813 & .476 \\
\hline
\end{tabular}

a Dependent Variable: Haplotype

Model summary

\begin{tabular}{lcccc}
\hline Model & $\mathbf{R}$ & $\begin{array}{c}\mathbf{R} \\
\text { square }\end{array}$ & $\begin{array}{c}\text { Adjusted } \mathbf{R} \\
\text { square }\end{array}$ & $\begin{array}{c}\text { SE of the } \\
\text { estimate }\end{array}$ \\
\hline 1 & $.550(\mathrm{a})$ & .302 & -.395 & .2602665 \\
\hline a Predictors: (Constant), Cu_Daging, Cd_Daging, Pb_Daging
\end{tabular}

Table 7. Stepwise linear regression test with nucleotidedependent variable and bioaccumulation of $\mathrm{Pb}, \mathrm{Cd}$, and $\mathrm{Cu}$, as the independent

\section{Coefficient (a)}

\begin{tabular}{|c|c|c|c|c|c|c|}
\hline & \multirow[t]{2}{*}{ Model } & \multicolumn{3}{|c|}{$\begin{array}{l}\text { Unstandardized Standardized } \\
\text { coefficients coefficients }\end{array}$} & & \multirow{2}{*}{$\begin{array}{c}\text { Sig. } \\
\text { SE }\end{array}$} \\
\hline & & B & SE & Beta & & \\
\hline \multirow[t]{2}{*}{1} & (Constant) & .010 & .002 & & 4.390 & .007 \\
\hline & $\mathrm{Cu}$ _Daging & -.002 & .001 & -.816 & -3.151 & .025 \\
\hline
\end{tabular}

a Dependent Variable: Haplotype

Model summary

\begin{tabular}{ccccc}
\hline Model & $\mathbf{R}$ & $\begin{array}{c}\mathbf{R} \\
\text { square }\end{array}$ & $\begin{array}{c}\text { Adjusted } \mathbf{R} \\
\text { square }\end{array}$ & $\begin{array}{c}\text { SE of the } \\
\text { estimate }\end{array}$ \\
\hline 1 & $.816(\mathrm{a})$ & .665 & .598 & .0033473 \\
\hline
\end{tabular}

a Predictors: (Constant), $\mathrm{Cu}$ _Daging, Cd_Daging, $\mathrm{Pb}$ _Daging
In conclusion, there were restrictions to gene flow even on very small geographic scales in S. fuscescens. Larval behavior, motility and competition for suitable habitat in the studied organisms may lead to more influence of biological factors for dispersal. Source of heavy metal pollution in Seribu Island assumed to come from similar sources. Heavy metal pollution might affect genetic diversity in Seribu Islands, in addition to other factors such as fishing activities, adsorption mechanism, and influence of the season.

\section{ACKNOWLEDGEMENTS}

This project was carried out and granted within the frame of Insetif Riset Nasional (INSINAS) the Indonesian State Ministry for Research and Technology (RISTEK), Jakarta, Indonesia. We thank the following organizations that supported this work, i.e., Seribu Island Marine National Park Officers, Jakarta, Indonesia, Marine Biodiversity and Biosystematics Laboratory, Bogor Agricultural University, Indonesia and Marine Science and Technology Diving School, Bogor, Indonesia.

\section{REFERENCES}

Akbar N, Zamani NP, Madduppa HH. 2014. Genetic diversity of yellowfin tuna (Thunnus albacares) from two populations in the Moluccas Sea, Indonesia. Depik 3: 65-73.

Allison EH, Ellis F. 2001. The Livelihoods Approach and Management of Small-scale Fisheries. Marine Policy 25: 377-388. $\square$

APHA [American Public Health Association]. 2012. Standard Method for The Examination of Water and Wastewater. 22th edition. American Public Health Association, Washington, DC.

Authman MMN, Zaki MS, Khallaf EA, Abbas HH. 2015. Use of Fish as Bio-indicator of the Effects of Heavy Metals Pollution. J Aquac Res Dev 6: 328. DOI: 10.4172/2155-9546.1000328

Badjeck MC, Allison EH, Hals AS, Dulvy NK. 2010. Impacts of climate variability and change on fishery-based livelihoods. Mar Pol 34: 375383. $\square$

Bálint M, Domisch S, Engelhardt CHM, Haase P, Lehrian S, Sauer J, Theissinger K, Pauls SU, Nowak C. 2011. Cryptic biodiversity loss linked to global climate change. Nature Clim Ch 1: 313-318.

Brinkhoff T. 2011. The principal agglomerations of the world. Available: http://www.citypopulation.de. [18 August 2018]

BSN [Badan Standardisasi Nasional]. 2011. Penentuan Kadar Logam Berat Timbal $(\mathrm{Pb})$ dan Kadmium (Cd) Pada Produk Perikanan. Jakarta. 2354. 5: 2011. [Indonesian]

Burke L, Reytar K, Spalding M, Perry AI. 2012. Reefs at Risk Revisited in The Coral Triangle. World Resource Institute, Washington DC.

Cleary DFR, Suharsono, Hoeksema BW. 2006. Coral diversity across a disturbance gradient in the Pulau Seribu reef complex off Jakarta, Indonesia. Biodivers Conserv 15: 3653-3674.

Crosby MP, Reese ES. 1996. A Manual for Monitoring Coral Reefs With Indicator Species: Butterflyfishes as Indicators of Change on Indo Pacific Reefs. Office of Ocean and Coastal Resource Management, National Oceanic and Atmospheric Administration, Silver Spring, MD.

England PR, Osler GHR, Woodworth LM, Montgomery ME, Briscoe DA, Frankham R. 2003. Effects of intense versus diffuse population bottlenecks on microsatellite genetic diversity and evolutionary potential. Conserv Genet 4: 595-604.

Excoffier L, Lischer H. 2009. Arlequin ver 3.5 user manual; An integrated software package for population genetics data analysis. Swiss Institute of Bioinformatics, Lausanne, Switzerland.

Fahlevy K, FK Yudha, W Andika, AE Suprianto, Nadya Jeny Irianda, Mas Irfanto, Beginer Subhan, Hawis Madduppa. 2018. Assessing fish community structure at two different coral reef depths around Seribu 
Islands, Jakarta. Jurnal Ilmu Kelautan Kepulauan 1 (1): 15-29. [Indonesian]

Fahlevy K, Khodijah S, Nasrullah IA, Fathihatunnisa R, Subhan B, Madduppa H. 2017. Site and depth influence on coral reef structure and composition in Seribu Islands, Jakarta. Aceh J Anim Sci 2 (1): 28-38.

FAO. 1983. Manual of methods in aquatic environment research [Part 9. Analyses of metals and organochlorines in fish]. FAO Fish Tech Pap. 212. Food and Agriculture Organization, Rome.

Frankham R. 1995. Inbreeding and extinction: a threshold effect. Conserv Biol 9 (4): 792-799.

Garza JC, Williamson EG. 2001. Detection of reduction in population size using data from microsatellite loci. Mol Ecol 10: 305-318.

Hoey AS, DR Bellwood. 2011. Suppression of herbivory by macroalgal density: a critical feedback on coral reefs? Ecol Lett 14: 267-273.

Hoey AS, SJ Brandl, DR Bellwood. 2013. Diet and cross-shelf distribution of rabbitfishes (f. Siganidae) on the northern Great Barrier Reef: implications for ecosystem function. Coral Reefs 32: 973-984.

Jennings S, Polunin N. 1996. Impacts of Fishing on Tropical Reef Ecosystem. Ambio 25: 44-49.

Kousar S, M Javed. 2015. Diagnosis of metals induced DNA damage in fish using comet assay. Pak Vet J 35 (2): 168-172.

Kulbicki M, Bozec YM, Green A. 2005. Implications of biogeography in the use of butterflyfishes (Chaetodontidae) as indicators for Western and Central Pacific areas. Aquat Conserv Mar Freshw Ecosyst 15: 109-126.

Lande R. 1988. Genetics and demography in biological conservation. Science 241: 1455-1460

Madduppa H, J Timm, M Kochzius. 2018. Reduced genetic diversity in clown anemonefish (Amphiprion ocellaris) in exploited reefs of the Spermonde Archipelago, Indonesia. Front Mar Sci 5: 80. DOI: 10.3389/fmars.2018.00080

Madduppa HH, Ferse SCA, Aktani U, Palm HW. 2012. Seasonal trends and fish-habitat associations around Pari Island, Indonesia: setting a baseline for environmental monitoring. Environ Biol Fish. DOI 10.1007/s10641-012-0012-7
Madduppa HH, Subhan B, Suparyani E, Siregar AM, Arafat D, Tarigan SA, Alimuddin, Khairudi D, Rahmawati F, Bramandito A. 2013. Dynamics of fish diversity across an environmental gradient in the Seribu Islands reefs off Jakarta. Biodiversitas 14 (1). DOI: $10.13057 /$ biodiv/d140103

Miller I, Sweatman H. 2004. Status of Coral Reefs In Australia and Papua New Guinea. In: Wilkinson C (eds.). Status of Coral Reef of The World. Global Coral Reef Network Management (GCRNM). Townsville, Australia. $\square$

Nugroho F, NP Zamani, H Madduppa. 2018. The Effect of Organic Sediment Content on Coral Diversity In Karimunjawa Island, Indonesia. Jurnal Ilmu dan Teknologi Kelautan Tropis. 10 (1): 79-86. [Indonesian]

Rozas JJ, Sanchez-DelBarrio C, Messequer X, Rozas R. 2003. DnaSP. DNA polymorphism analyses by the coalescent and other methods. Bioinformatics 19: 2496-2497.

Spielman D, Brook BW, Frankham R. 2004. Most species are not driven to extinction before genetic factors impact them. Proc Natl Acad Sci USA 101: 15261-15264.

Timm J, Dohna T, Madduppa H., Neuhaus A, Kochzius M. 2017. Smallscale genetic population structure of coral reef organisms in Spermonde Archipelago, Indonesia. Front Mar Sci. DOI: 10.3389/fmars.2017.00294

Wilkinson C. 2008. Status of Coral Reefs of the World. Global Coral Reef Monitoring Network (GCRMN) and Reef and Rainforest Research Centre, Townsville, Australia. $\square$

Williams TM, Rees JG, Setiapermana D. 2000. Metals and trace organic compounds in sediments and waters of Jakarta Bay and the Pulau Seribu Complex, Indonesia. Mar Pollut Bull 40: 277-285.

Woodland DJ. 2001. Siganidae. In: Carpenter KE, Niem VH (eds) FAO species identification guide for fishery purposes. The living marine resources of the Western Central Pacific, vol 6. Food and Agriculture Organization, Rome.

Zhang Y, Wang Y, Yu R, Zhang S, Wu Z. 2008. Effects of heavy metals $\mathrm{Cd}^{2+}, \mathrm{Pb}^{2+}$, and $\mathrm{Zn}^{2+}$ on DNA damage of loach Misgurnus anguillicaudatus. Front Biol China 3 (1): 50-54. 